
УДК 618.5-089.888.61

DOI 10.11603/1811-2471.2021.v.i1.11733

\title{
ПОРІВНЯЛЬНИЙ АНАЛІЗ ІНТРАОПЕРАЦІЙНОЇ КРОВОВТРАТИ ПРИ ПЕРЕДЧАСНИХ ПОЛОГАХ ПІД ЧАС КЕСАРЕВОГО РОЗТИНУ ЗА КЛАСИЧНИМ СПОСОБОМ ТА ЗА МОДИФІКОВАНОЮ МЕТОДИКОЮ
}

\section{Одеський національний медичний університет}

\author{
๑д. О. Григурко
}

РЕЗЮМЕ. Мета - провести порівняльний аналіз об'єму інтраопераційної крововтрати при кесаревому розтині (КР) за класичним способом та при застосуванні модифікованої методики в умовах передчасних пологів (ПП).

Матеріал і методи. Проведено порівняльний аналіз 59 випадків передчасних пологів, розродження при яких було проведено абдомінальним шляхом. Основну групу (І клінічна) склали 29 пацієнток, у яких операція кесаревого розтину виконувалась згідно з запропонованою модифікованою методикою, порівняльну групу (II клінічна) - 30 пацієнток, які були прооперовані класичним способом кесаревого розтину. Для більш достовірного аналізу кожна клінічна група була поділена на дві підгрупи в залежності від терміну вагітності (29-33 тижні 6 днів та 34-36 тижнів і 6 днів відповідно). Головні відмінності запропонованої методики абдомінального розродження полягають у використанні удосконаленого способу входження до черевної порожнини та в одномоментному ушиванні рани на матці двома операторами, починаючи від кутів країв рани неперервним однорядним вікриловим швом із фіксуючим зашморгом на кожному з кінців двох ниток. У випадках народження дітей на ранніх термінах, до 30 тижнів гестації, проводився корпоральний розріз на матці та їх народження в цілому плідному міхурі.

Результати. У процесі дослідження ми виявили, що застосування модифікованої методики абдомінального розродження сприяє зменшенню величини інтраопераційної крововтрати при ПП майже на 300 мл (р<0,001), мінімізує розвиток масивної акушерської кровотечі (МАК), практично анулює потребу в проведенні інтраопераційної гемотрансфузії та гістеректомії $(p<0,05)$.

Висновок. Отримані нами дані підтверджують ефективність застосування удосконаленої методики абдомінального розродження для зменшення об'єму інтраопераційної крововтрати в умовах ПП.

КлючовІ СлОВА: кесарів розтин; передчасні пологи; крововтрата; модифікація.

Вступ. Одним із найчастіших та тяжких ускладнень абдомінального розродження $\epsilon$ акушерські кровотечі (АК) $[4,6]$. Їх частота коливається від 2,5 \% до 8 \% від загальної кількості пологів та нерідко призводить до випадків материнської смертності $[5,6]$. У сучасних літературних даних відомості щодо АК переважно присвячені доношеній вагітності $[5,15,17]$. Проте, частота передчасних пологів (ПП) у світі коливається в широких межах від 5 \% до 25 \% та не має тенденції до зменшення [2, 3]. В Україні цей показник у середньому становить 4,7 \% і продовжує зростати [1, 3]. Відомо, що передчасний термін вагітності не $є$ показанням до кесаревого розтину, за винятком наявності конкретних акушерських причин $[1,3]$. Як правило, показання до абдомінального розродження на ранніх термінах гестації асоційовані з передчасним відшаруванням плаценти, прееклампсією тяжкого ступеня, багатоплідною вагітністю [1, 2]. У меншій мірі до оперативного розродження вдаються у разі затримки внутрішньоутробного розвитку плода, неправильного передлежання та положення плода $[1,3,4]$. Очевидним є факт, що стан новонароджених залежить насамперед від терміну вагітності $[1,8]$. Проте, не менш важливою залишається техніка виконання кесаревого розтину [4, 7]. Удосконалення класичних етапів абдомінального розродження може бути допоміжним способом зменшення трав- матизму плода та інтраопераційної крововтрати, пов' язаної з хірургічним втручанням $[4,7,11]$.

Матеріал і методи дослідження. Для вирішення поставленої мети нами проведено порівняльний аналіз 59 випадків передчасних пологів, розродження яких було проведено абдомінальним шляхом. Критерії включення у дослідження передчасні пологи (ПП) у терміні 22-36 тижнів і 6 днів гестації; затримка внутрішньоутробного розвитку плода (ЗВУР); антенатально виявлені вроджені вади розвитку плода (ВВР); неправильне передлежання та положення плода; багатоплідна вагітність. Критерієм виключення із дослідження був доношений термін вагітності.

Відповідно до дизайну дослідження було сформовано дві групи пацієнток: основна група (І клінічна) - 29 пацієнток, у яких операція кесаревого розтину виконувалась згідно із запропонованою модифікованою методикою; порівняльна група (II клінічна) - 30 пацієнток, які були прооперовані класичним способом кесаревого розтину. Для більш достовірного аналізу кожна клінічна група була поділена на дві підгрупи залежно від терміну вагітності (29-33 тижні 6 днів та 3436 тижнів і 6 днів відповідно).

Хірургічне втручання у пацієнток виконували у межах чинного наказу МО3 України від 27.12.2011 № 977 [21] лікарі вищої категорії в аку- 
Огляди літератури, оригінальні дослідження, погляд на проблему, випадок з практики, короткі повідомлення шерському відділенні Херсонської обласної клінічної лікарні та 5 міському пологовому будинку м. Одеса (клінічні бази кафедри акушерства та гінекології ОНМедУ). Метод оперативного розродження, який використовували в ході дослідження, представляє собою модифікацію методики кесаревого розтину за M. Stark із використанням декількох нових технічних підходів $[19,20]$. 3 метою зменшення об'єму інтраопераційної крововтрати застосовували удосконалений спосіб входження до черевної порожнини, ушивання рани на матці одночасно двома операторами, починаючи від кутів країв рани неперервним однорядним вікриловим швом із фіксуючим зашморгом на кожному з кінців двох ниток $[19,20]$. Для покращення стану новонароджених дітей був застосований мультидисциплінарний організаційний підхід [24]. Модифікований кесарів розтин у деяких випадках виконували у стаціонарі дитячої лікарні III рівня з метою надання новонародженому максимально швидкої висококваліфікованої допомоги силами суміжних спеціалістів [20, 24]. у випадках народження дітей на ранніх термінах, до 30 тижнів гестації, при тазовому передлежанні плода, немовлят із вродженими вадами розвитку проводили корпоральний розріз на матці та їх народження в цілому плідному міхурі $[9,16,17]$. Усім

вагітним дослідження виконані згідно з галузевими стандартами [21], отримана письмова добровільна згода на участь у дослідженні. Об'єм інтраопераційної крововтрати визначали гравіметричним методом, з наступним підрахунком за формулою Лібова [19].

Статистичне опрацювання одержаних peзультатів проведено з використанням додатка $\mathrm{R}$ програми Microsoft Exel 7.0. Вірогідність відмінностей у малих статистичних групах оцінювали за допомогою тесту Стьюдента (t-test). Порогова величина р-рівня - 0,05\%.

Порівняльний аналіз клініко-анамнестичних та можливих передопераційних предикторів свідчить про репрезентативність обох клінічних груп (табл. 1, 2). Статистично достовірна різниця виявлена серед методів знеболювання пацієнток $(p<0,05)$. У двох групах дослідження вибір способу анестезії проводився індивідуально, з урахуванням стану роділлі та плода, категорії ургентності операції і показань до виконання кесаревого розтину. У групі порівняння більше ніж у 80 \% випадків застосовували спинномозкову анестезію (CMA), що може бути пов'язано з III-IV категорією ургентності та високою кваліфікацією лікаря анестезіолога (див. табл. 2). За антропометричними даними достовірних розбіжностей між паці-

Таблиця 1. Порівняльний аналіз деяких передопераційних предикторів у двох клінічних групах (n=59)

\begin{tabular}{|c|c|c|c|c|c|}
\hline \multirow[b]{2}{*}{ Показник } & \multirow[b]{2}{*}{ Група } & \multicolumn{2}{|c|}{ Підгрупа } & \multirow[b]{2}{*}{$\Sigma$} & \multirow[b]{2}{*}{$\mathrm{P}$} \\
\hline & & $\begin{array}{c}\text { 29-33 тижні } \\
\text { і } 6 \text { днів гестації }\end{array}$ & $\begin{array}{c}\text { 34-36 тижнів } \\
\text { і } 6 \text { днів гестації }\end{array}$ & & \\
\hline 1 & 2 & 3 & 4 & 5 & 6 \\
\hline \multirow[t]{2}{*}{ Вік, років } & $\begin{array}{l}\text { Основна } \\
\text { група } \\
(n-29)\end{array}$ & $\begin{array}{c}28,25 \pm 1,29 \\
95 \% \text { Дl: } 25,73-30,77 \\
20-35 \\
n=12\end{array}$ & $\begin{array}{c}28,41 \pm 1,92 \\
95 \% \text { Дl: } 24,64-32,18 \\
17-41 \\
n=17\end{array}$ & $\begin{array}{c}28,34 \pm 1,23 \\
95 \% \text { Дl: } 25,94-30,75 \\
17-41 \\
n=29\end{array}$ & 0,95 \\
\hline & $\begin{array}{l}\text { Порівняльна } \\
\text { група } \\
(\mathrm{n}-30)\end{array}$ & $\begin{array}{c}28,35 \pm 1,11 \\
95 \% \text { ДІ: } 26,17-30,52 \\
19-42 \\
n=23\end{array}$ & $\begin{array}{c}30,14 \pm 1,62 \\
95 \% \text { ДІ: } 26,96-33,33 \\
24-35 \\
n=7\end{array}$ & $\begin{array}{c}28,77 \pm 0,93 \\
95 \% \text { ДІ: } 26,95-30,59 \\
19-42 \\
n=30\end{array}$ & 0,424 \\
\hline \multirow[t]{2}{*}{ Зріст, см } & $\begin{array}{l}\text { Основна } \\
\text { група } \\
(n-29)\end{array}$ & $\begin{array}{c}165,5 \pm 1,64 \\
95 \text { \% ДІ: } 162,29-168,71 \\
156-175 \\
n=12\end{array}$ & $\begin{array}{c}161,35 \pm 1,36 \\
95 \text { \% ДІ: } 158,69-164,02 \\
154-170 \\
n=17\end{array}$ & $\begin{array}{c}163,07 \pm 1,1 \\
95 \text { \% ДІ: } 160,92-165,22 \\
154-175 \\
n=29\end{array}$ & 0,061 \\
\hline & $\begin{array}{l}\text { Порівняльна } \\
\text { група } \\
(\mathrm{n}=30)\end{array}$ & $\begin{array}{c}165,04 \pm 1,28 \\
95 \% \text { Дl: } 162,54-167,55 \\
149-176 \\
n=23 \\
\end{array}$ & $\begin{array}{c}163,43 \pm 2,48 \\
95 \% \text { ДІ: } 158,57-168,28 \\
154-175 \\
n=7\end{array}$ & $\begin{array}{c}164,67 \pm 1,12 \\
95 \% \text { Дl: } 162,47-166,87 \\
149-176 \\
n=30 \\
\end{array}$ & 0,55 \\
\hline \multirow[t]{2}{*}{ Maca, кг } & $\begin{array}{l}\text { Основна } \\
\text { група }(n=29)\end{array}$ & $\begin{array}{c}71,08 \pm 4,02 \\
95 \% \text { ДІ: } 63,2-78,97 \\
52-104 \\
n=12\end{array}$ & $\begin{array}{c}79,88 \pm 3,75 \\
95 \% \text { Дl: } 72,54-87,23 \\
54-110 \\
n=17\end{array}$ & $\begin{array}{c}76,24 \pm 2,83 \\
95 \% \text { ДІ: } 70,7-81,79 \\
52-110 \\
n=29\end{array}$ & 0,121 \\
\hline & $\begin{array}{l}\text { Порівняльна } \\
\text { група }(n=30)\end{array}$ & $\begin{array}{c}74,52 \pm 3,53 \\
95 \% \text { ДІ: } 67,61-81,44 \\
51-106 \\
n=23\end{array}$ & $\begin{array}{c}66,71 \pm 4,3 \\
95 \% \text { ДI: } 58,29-75,14 \\
55-84 \\
\mathrm{n}=7\end{array}$ & $\begin{array}{c}72,7 \pm 2,92 \\
95 \% \text { ДІ: } 66,98-78,42 \\
51-106 \\
n=30\end{array}$ & 0,262 \\
\hline
\end{tabular}


Огляди літератури, оригінальні дослідження, погляд на проблему, випадок з практики, короткі повідомлення

Продовження табл. 1

\begin{tabular}{|c|c|c|c|c|c|}
\hline 1 & 2 & 3 & 4 & 5 & 6 \\
\hline \multirow[t]{2}{*}{$\begin{array}{l}\text { Гемоглобін } \\
\text { до операції, } \\
\text { г/л }\end{array}$} & $\begin{array}{l}\text { Основна } \\
\text { група }(n=29)\end{array}$ & $\begin{array}{c}118,67 \pm 2,81 \\
95 \% \text { मl: } 113,15-124,18 \\
100-136 \\
n=12\end{array}$ & $\begin{array}{c}117,35 \pm 2,48 \\
95 \% \text { ДІ: } 112,49-122,22 \\
100-135 \\
n=17\end{array}$ & $\begin{array}{c}117,9 \pm 1,83 \\
95 \text { \% ДІ: } 114,3-121,49 \\
100-136 \\
n=29\end{array}$ & 0,768 \\
\hline & $\begin{array}{l}\text { Порівняльна } \\
\text { група }(n=30)\end{array}$ & $\begin{array}{c}113,74 \pm 2,23 \\
95 \% \text { ДІ: } 109,37-118,1 \\
96-135 \\
n=23\end{array}$ & $\begin{array}{c}109,14 \pm 1,79 \\
95 \% \text { ДІ: } 105,63-112,65 \\
102-116 \\
n=7\end{array}$ & $\begin{array}{c}112,67 \pm 1,78 \\
95 \text { \% ДІ: } 109,18-116,16 \\
96-135 \\
n=30\end{array}$ & 0,246 \\
\hline \multirow[t]{2}{*}{$\begin{array}{l}\text { Фібриноген, } \\
\text { г/л }\end{array}$} & $\begin{array}{l}\text { Основна } \\
\text { група }(n=29)\end{array}$ & $\begin{array}{c}3,47 \pm 0,06 \\
95 \% \text { Дl: } 3,34-3,59 \\
3,2-3,9 \\
n=12\end{array}$ & $\begin{array}{c}3,48 \pm 0,05 \\
95 \% \text { ДI: } 3,37-3,58 \\
3-3,8 \\
n=17\end{array}$ & $\begin{array}{c}3,47 \pm 0,04 \\
95 \% \text { Дl: } 3,39-3,55 \\
3-3,9 \\
n=29\end{array}$ & 0,907 \\
\hline & $\begin{array}{l}\text { Порівняльна } \\
\text { група }(n=30)\end{array}$ & $\begin{array}{c}3,42 \pm 0,09 \\
95 \% \text { ДI: } 3,25-3,59 \\
2,7-4,1 \\
n=23\end{array}$ & $\begin{array}{c}3,29 \pm 0,07 \\
95 \% \text { ДI: } 3,14-3,43 \\
3,1-3,6 \\
n=7\end{array}$ & $\begin{array}{c}3,39 \pm 0,07 \\
95 \% \text { ДІ: } 3,25-3,52 \\
2,7-4,1 \\
n=30 \\
\end{array}$ & 0,427 \\
\hline
\end{tabular}

Таблиця 2. Порівняльний аналіз деяких передопераційних предикторів у двох клінічних групах (n=59)

\begin{tabular}{|c|c|c|c|c|c|c|c|}
\hline \multirow[t]{2}{*}{ Показник } & \multicolumn{2}{|c|}{$\begin{array}{l}\text { I клінічна група } \\
\text { (основна) (n=29) }\end{array}$} & \multicolumn{2}{|c|}{$\begin{array}{c}\text { II клінічна група } \\
\text { (порівняльна) }(\mathrm{n}=30)\end{array}$} & \multicolumn{2}{|c|}{$\Sigma(n=59)(\%)$} & \multirow[t]{2}{*}{$\mathrm{P}$} \\
\hline & $\mathrm{n}$ & $\%$ & $\mathrm{n}$ & $\%$ & $\mathrm{n}$ & $\%$ & \\
\hline Первістки & 16 & 55,2 & 17 & 56,7 & 33 & 55,94 & 1 \\
\hline Повторнонароджуючі & 13 & 44,8 & 13 & 43,3 & 26 & 44,06 & 1 \\
\hline $\begin{array}{l}\text { Обтяжений акушерсько- } \\
\text { гінекологічний анамнез (ОАГА) }\end{array}$ & 10 & 34,5 & 15 & 50 & 25 & 42,37 & 1 \\
\hline ETH & 15 & 51,7 & 5 & 16,7 & 20 & 33,90 & $<0,05$ \\
\hline CMA & 14 & 48,3 & 25 & 83,3 & 39 & 66,10 & $<0,05$ \\
\hline Багатоплідна вагітність & 3 & 10,3 & 1 & 3,33 & 4 & 6,78 & 1 \\
\hline
\end{tabular}

єнтками обох клінічних груп знайдено не було $(p>0,05)$.

У проведеному дослідженні переважали первістки, майже у 50 \% жінок був обтяжений акушерсько-гінекологічний анамнез (медичні або самовільні викидні), відзначено 4 випадки багатоплідної вагітності, проте різниці між показниками у двох групах не виявлено ( $p>0,05)$. Рівні гемоглобіну та фібриногену на передопераційному етапі були в межах норми $(p>0,05)$ (див. табл. 1, 2).
Основним показанням до кесаревого розтину в обох клінічних групах було неправильне положення плода на тлі передчасного розриву плідних оболонок (ПРПО) - 37,3 \%, передчасне відшарування нормально розташованої плаценти (ПВНРП) - 30,5 \%, прееклампсія тяжкого ступеня 10,2 \%, в меншій мірі - затримка внутрішньоутробного розвитку плода (ЗВУР), дистрес плода, багатоплідна вагітність та випадання пульсуючих петель пуповини - 22,13 \%, без статистичної різниці між клінічними групами (табл. 3).

Таблиця 3. Порівняльний аналіз показань до кесаревого розтину в двох клінічних групах (n=59)

\begin{tabular}{|c|c|c|c|c|c|c|c|}
\hline \multirow[t]{2}{*}{ Показник } & \multicolumn{2}{|c|}{$\begin{array}{l}\text { I клінічна група } \\
\text { (основна) (n=29) }\end{array}$} & \multicolumn{2}{|c|}{$\begin{array}{c}\text { II клінічна група } \\
\text { (порівняльна) }(n=30)\end{array}$} & \multicolumn{2}{|c|}{$\Sigma(n=59)(\%)$} & \multirow[t]{2}{*}{$\mathrm{p}$} \\
\hline & $\mathrm{n}$ & $\%$ & $n$ & $\%$ & $\mathrm{n}$ & $\%$ & \\
\hline 1 & 2 & 3 & 4 & 5 & 6 & 7 & 8 \\
\hline ПВНРП & 8 & 27,6 & 10 & 33,3 & 18 & 30,5 & 1 \\
\hline $\begin{array}{l}\text { Неправильне положення плода } \\
+ \text { передчасний розрив плідних } \\
\text { оболонок (ПРПО) }\end{array}$ & 9 & 31,0 & 13 & 43,3 & 22 & 37,3 & 1 \\
\hline Прееклампсія тяжкого ступеня & 4 & 13,8 & 2 & 6,7 & 6 & 10,2 & 1 \\
\hline Дистрес плода & 3 & 10,3 & 0 & 0 & 3 & 5,08 & 1 \\
\hline
\end{tabular}


Огляди літератури, оригінальні дослідження, погляд на проблему, випадок з практики, короткі повідомлення

Продовження табл. 3

\begin{tabular}{|l|c|c|c|c|c|c|c|}
\hline \multicolumn{1}{|c|}{1} & 2 & 3 & 4 & 5 & 6 & 7 & 8 \\
\hline $\begin{array}{l}\text { Затримка внутрішньоутробного } \\
\text { розвитку плода (ЗВуР) ІІІ ст. }\end{array}$ & 1 & 3,45 & 4 & 1,33 & 5 & 8,58 & 1 \\
\hline $\begin{array}{l}\text { Багатоплідна вагітність } \\
\text { (монохоріальна, моноамніотична) }\end{array}$ & 3 & 10,3 & 1 & 3,33 & 4 & 6,78 & 1 \\
\hline $\begin{array}{l}\text { Випадання пульсуючих петель } \\
\text { пуповини }\end{array}$ & 1 & 3,45 & 0 & 0 & 1 & 1,69 & 1 \\
\hline
\end{tabular}

Результати й обговорення. Проблема передчасних пологів (ПП) не втрачає своєї актуальності в сучасному акушерстві і залишається однією з головних причин неонатальної смертності $[1,15,17]$. Частота ПП в Херсонській обласній лікарні на 2019 рік склала близько 10,2%, в 5 пологовому будинку м. Одеса близько 12 \%. Акушерська спільнота не має єдиної думки щодо способу народження недоношених малюків, адже метод розродження залежить від багатьох факторів $[7,12,13]$. Проте, до 28 тижнів гестації та після 34 тижнів рекомендовано надавати перевагу вагінальним пологам (ВП) $[1,3,17,18]$. Оскільки плановий КР, порівняно з ВП, збільшує материнську захворюваність і не покращує перинатальних результатів для недоношених новонароджених $[1,3,10]$.

Кесарів розтин при ПП має свої особливості, як правило, він обумовлений кровотечею $[5,22$, 23]. Домінуючими причинами масивної акушерської крововтрати (МАК) $\epsilon$ передлежання плаценти з аномалією ії інвазії, тяжка прееклампсія, низький рівень експресії рецепторів прогестерону в міометрії і децидуальній тканині, мала кількість окситоцинових рецепторів в міометрію матки $[5,6,9,23]$. Аналізуючи показання до КР, очевидним $€$ факт проведення хірургічного втручання в умовах крововтрати. Тому, окрім застосування медикаментозних методів зупинки кровотечі, важливо оптимізувати організаційний підхід та техніку оперативного розродження $[9,12,14,22]$.

Застосування модифікованої методики кесаревого розтину, принцип якої полягає в раціональній роботі операційної бригади, а саме хірурга та асистента $[19,20]$, перш за все сконцентровано на швидкій ліквідації головного джерела кровотечі ушиванні матки. Ушивання виконується одночасно двома операторами, починаючи від кутів країв рани неперервним однорядним вікриловим швом з фіксуючим зашморгом на кожному з кінців двох ниток $[19,20]$. Адже це ділянка, де проходять основні судини, і як правило утворюються масивні гематоми. Крім того, зменшенню величини крововтрати сприяє удосконалений спосіб входження до черевної порожнини. Він передбачає розріз апоневрозу скальпелем по середній лінії довжиною до 2 см, захоплення вказівними пальцями очеревини і розтягнення всіх шарів передньої стінки тупим шляхом двома хірургами одночасно [19, 20]. Це дає змогу не лише пришвидшити час до моменту вилучення плода, а й зберегти відповідну архітектоніку судин та максимально мінімізувати потребу в проведенні додаткового гемостазу. Ушивання шарів черевної стінки (апоневрозу та шкіри) відбувається за аналогічно наведеною методикою $[19,20]$.

Результати, отримані в процесі дослідження, переконливо доведені та можуть свідчити про ефективність використаної методики. Головною перевагою запропонованого способу кесаревого розтину $\epsilon$ зменшення інтраопераційної крововтрати майже на 300 мл (табл. 4, 5).

В основній клінічній групі, в якій застосовували модифікований спосіб КР, середній об' єм інтраопераційної крововтрати склав $(350 \pm 114,17)$ мл, проти $(640,67 \pm 396,44)$ мл у групі порівняння $(p<0,001)$ (табл. 4). Не дивлячись на те, що розміри матки та плацентарного ложа в ранні терміни вагітності менші, величина крововтрати у пацієнток II клінічної групи в терміні гестації 29-33 тижні і 6 днів виявилась більшою, ніж у жінок з більш пізнім терміном вагітності (табл. 4). Скоріше за все, це обумовлено малою кількістю рецепторів до окситоцину та незначною чутливістю міометрія до нього, що негативно впливає на скорочувальну діяльність матки. Тому оптимізація техніки абдомінального розродження на тлі підвищеної крововтрати $\epsilon$ особливо актуальною при ПП. У пацієнток I підгрупи, які були прооперовані за класичною методикою КР, діагностували 2 випадки патологічної крововтрати (до 1,5 \% від загальної маси тіла) та 4 випадки МАК, коли об'єм крововтрати перевищував 1,5 \% від маси тіла. Ці пацієнтки були в стані геморагічного шоку та потребували інтраопераційної гемотрансфузії (табл. 5). Подібних ускладнень в основній групі дослідження виявлено не було, проте різниця не достовірна ( $p>0,05)$.

Підвищену крововтрату в II клінічній групі підтверджують показники загального аналізу крові (ЗАК) (p>0,05) (табл. 6). Середній рівень гемоглобіну $(\mathrm{Hb})$ в післяопераційному періоді склав $(100,4 \pm$ $2,13)$ г/л, що відповідає анемії легкого ступеня. У пацієнток, які народжували у терміні вагітності до 
Огляди літератури, оригінальні дослідження, погляд на проблему, випадок з практики, короткі повідомлення Таблиця 4. Порівняльний аналіз об'єму інтраопераційної крововтрати у двох клінічних групах (n=59)

\begin{tabular}{|c|c|c|c|c|c|}
\hline \multirow[b]{2}{*}{ Група } & \multicolumn{5}{|c|}{ Крововтрата, мл } \\
\hline & $\begin{array}{c}\text { середнє } \\
\text { значення }\end{array}$ & $\begin{array}{c}\text { помилка } \\
\text { визначення } \\
\text { середнього }\end{array}$ & $\begin{array}{l}\text { стандартне } \\
\text { відхилення }\end{array}$ & $\begin{array}{c}\text { діапазон } \\
\text { крововтрати (мл) }\end{array}$ & $\begin{array}{l}95 \% \text { довірчий } \\
\text { індекс (ДІ) }\end{array}$ \\
\hline $\begin{array}{l}\text { I клінічна група } \\
\text { (основна) }(n=29)\end{array}$ & 350 & 21,2 & 114,17 & $200-800$ & $308,45-391,55$ \\
\hline $\begin{array}{l}\text { II клінічна група } \\
\text { (порівняльна) } \\
(n=30)\end{array}$ & 640,67 & 72,38 & 396,44 & $350-2200$ & $498,8-782,53$ \\
\hline$\Sigma$ & 497,8 & 42,46 & 326,12 & $200-2200$ & $414,58-581,01$ \\
\hline$p$ & \multicolumn{5}{|c|}{$<0,001$} \\
\hline d Кохена & \multicolumn{5}{|c|}{$\begin{array}{c}0,99 \\
95 \% \text { ДІ: 0,82 - 1,15 }\end{array}$} \\
\hline
\end{tabular}

Таблиця 5. Порівняльний аналіз об'єму інтраопераційної крововтрати у двох клінічних підгрупах (n=59)

\begin{tabular}{|c|c|c|c|c|c|}
\hline \multirow[b]{2}{*}{ Показник } & \multirow[b]{2}{*}{ Група } & \multicolumn{2}{|c|}{ Підгрупа } & \multirow[b]{2}{*}{$\Sigma$} & \multirow[b]{2}{*}{$P$} \\
\hline & & $\begin{array}{l}\text { I (29-33 тижні } \\
\text { і } 6 \text { днів гестації) }\end{array}$ & $\begin{array}{l}\text { II (34-36 тижнів } \\
\text { і } 6 \text { днів гестації) }\end{array}$ & & \\
\hline \multirow[t]{4}{*}{$\begin{array}{l}\text { Крововтрата, } \\
\text { мл }\end{array}$} & $\begin{array}{l}\text { I клінічна } \\
\text { група } \\
\text { (основна) } \\
(\mathrm{n}=29) \\
\end{array}$ & $\begin{array}{c}341,67 \pm 22,89 \\
95 \% \text { ДІ: } 296,8-386,53 \\
200-500 \\
n=12 \\
\end{array}$ & $\begin{array}{c}355,88 \pm 32,9 \\
95 \% \text { ДІ: } 291,4-420,36 \\
250-800 \\
n=17 \\
\end{array}$ & $\begin{array}{c}350 \pm 21,2 \\
95 \text { \% ДІ: } 308,45-391,55 \\
200-800 \\
n=29\end{array}$ & 0,748 \\
\hline & \begin{tabular}{|c|} 
II клінічна \\
група \\
(порівняльна) \\
$(\mathrm{n}=30)$
\end{tabular} & $\begin{array}{c}694,35 \pm 90,78 \\
95 \% \text { ДІ: } 516,42-872,28 \\
350-2200 \\
n=23\end{array}$ & $\begin{array}{c}464,29 \pm 49,66 \\
95 \% \text { ДІ: } 366,96-561,61 \\
350-700 \\
n=7\end{array}$ & $\begin{array}{c}640,67 \pm 72,38 \\
95 \% \text { ДІ: } 498,8-782,53 \\
350-2200 \\
n=30\end{array}$ & 0,183 \\
\hline & $\Sigma$ & $\begin{array}{c}573,43 \pm 66,23 \\
95 \% \text { Дl: } 443,62-703,24 \\
200-2200 \\
n=35 \\
\end{array}$ & \begin{tabular}{|c|}
$387,5 \pm 28,75$ \\
$95 \%$ ДІ: $331,15-443,85$ \\
$250-800$ \\
$n=24$ \\
\end{tabular} & $\begin{array}{c}497,8 \pm 42,46 \\
95 \% \text { ДІ: } 414,58-581,01 \\
200-2200 \\
n=59\end{array}$ & 0,03 \\
\hline & $p$ & 0,009 & 0,086 & $<0,001$ & 0,148 \\
\hline
\end{tabular}

Таблиця 6. Порівняльний аналіз деяких лабораторних показників у двох клінічних групах (n=59)

\begin{tabular}{|c|c|c|c|c|c|}
\hline \multirow[b]{2}{*}{ Показник } & \multirow[b]{2}{*}{ Група } & \multicolumn{2}{|c|}{ Підгрупа } & \multirow[b]{2}{*}{$\Sigma$} & \multirow[b]{2}{*}{$\mathrm{P}$} \\
\hline & & $\begin{array}{c}\text { 29-33 тижні } \\
\text { і } 6 \text { днів гестації }\end{array}$ & $\begin{array}{l}\text { 34-36 тижнів } \\
\text { і } 6 \text { днів гестації }\end{array}$ & & \\
\hline \multirow[t]{2}{*}{$\begin{array}{l}\text { Гемоглобін, } \\
\text { г/л }\end{array}$} & $\begin{array}{l}\text { Основна група } \\
(n=29)\end{array}$ & $\begin{array}{c}112,42 \pm 2,71 \\
95 \% \text { ДІ: } 107,11-117,73 \\
91-125 \\
n=12\end{array}$ & $\begin{array}{c}110,88 \pm 1,88 \\
95 \% \text { ДІ: } 107,2-114,56 \\
98-130 \\
n=17\end{array}$ & $\begin{array}{c}111,52 \pm 1,55 \\
95 \% \text { ДІ: } 108,49-114,55 \\
91-130 \\
n=29\end{array}$ & 0,634 \\
\hline & $\begin{array}{l}\text { Порівняльна } \\
\text { група }(n=30)\end{array}$ & $\begin{array}{c}99,74 \pm 2,66 \\
95 \% \text { ДІ: } 94,53-104,95 \\
67-126 \\
n=23\end{array}$ & $\begin{array}{c}102,57 \pm 2,85 \\
95 \% \text { ДІ: } 96,98-108,16 \\
88-112 \\
n=7\end{array}$ & $\begin{array}{c}100,4 \pm 2,13 \\
95 \% \text { ДІ: } 96,22-104,58 \\
67-126 \\
n=30\end{array}$ & 0,583 \\
\hline \multirow[t]{2}{*}{$\begin{array}{l}\text { Фібриноген, } \\
\text { г/л }\end{array}$} & $\begin{array}{l}\text { Основна група } \\
(n=29)\end{array}$ & $\begin{array}{c}3,37 \pm 0,06 \\
95 \% \text { ДІ: } 3,34-3,59 \\
3,2-3,9 \\
n=12\end{array}$ & $\begin{array}{c}3,38 \pm 0,05 \\
95 \% \text { ДI: } 3,37-3,58 \\
3-3,8 \\
n=17\end{array}$ & $\begin{array}{c}3,37 \pm 0,04 \\
95 \% \text { ДІ: } 3,39-3,55 \\
3-3,9 \\
n=29\end{array}$ & 0,071 \\
\hline & $\begin{array}{l}\text { Порівняльна } \\
\text { група }(n=30)\end{array}$ & $\begin{array}{c}3,32 \pm 0,09 \\
95 \% \text { ДI: } 3,25-3,59 \\
2,7-4,1 \\
n=23\end{array}$ & $\begin{array}{c}3,19 \pm 0,07 \\
95 \% \text { Дl: } 3,14-3,43 \\
3,1-3,6 \\
n=7\end{array}$ & $\begin{array}{c}3,29 \pm 0,07 \\
95 \% \text { ДI: } 3,25-3,52 \\
2,7-4,1 \\
n=30\end{array}$ & 0,652 \\
\hline
\end{tabular}

34 тижнів, частіше діагностували анемію середнього ступеня тяжкості - $(99,74 \pm 2,66)$ г/л, найниж- чий рівень Нb дорівнював 67 г/л, що відповідало стану тяжкої анемії, який потребував проведення 
Огляди літератури, оригінальні дослідження, погляд на проблему, випадок з практики, короткі повідомлення гемотрансфузії та подальшої антианемічної терапії. Рівень вихідного Нь та фібриногену в породіль основної клінічної групи був у межах нижньої межі норми - $(111,52 \pm 1,55)$ г/л (р>0,05).

Для оцінки стану немовлят при народженні використовують різноманітні шкали (Баллард, Сільвермана), але найпростішим способом визначення категорії дітей, які потребують проведення реанімаційних заходів, поглибленої уваги неонатологів або призначення додаткових методів обстеження, $є$ шкала Апгар $[15,17,18]$. Результати проведеного нами дослідження демонструють, що більшість новонароджених були вилучені в стані, який орієнтований ближче до задовільного (табл. 7). Середня оцінка за школою Апгар на 1 хвилині життя в обох групах становила 6 балів. Очевидним $є$ факт, що маса тіла та довжина немовлят, які народилися на ранніх термінах гестації, $є$ меншою, порівняно з новонародженими в більш віддалені терміни вагітності (р<0,05) (табл. 7). Втім, цей аналіз не був метою нашої роботи та потребує подальших, більш поглиблених досліджень.

Таблиця 7. Порівняльний аналіз стану новонароджених за шкалою Апгар та антропометричними даними (n=59)

\begin{tabular}{|c|c|c|c|c|c|}
\hline \multirow[b]{2}{*}{ Показник } & \multirow[b]{2}{*}{ Група } & \multicolumn{2}{|c|}{ Підгрупа } & \multirow[b]{2}{*}{$\Sigma$} & \multirow[b]{2}{*}{$P$} \\
\hline & & $\begin{array}{c}\text { 29-33 тижні і } 6 \text { днів } \\
\text { гестації }\end{array}$ & $\begin{array}{c}\text { 34-36 тижнів і } 6 \text { днів } \\
\text { гестації }\end{array}$ & & \\
\hline \multirow[t]{2}{*}{$\begin{array}{l}\text { Стан плода за } \\
\text { шкалою Апгар, } \\
1 \text { хвилина життя }\end{array}$} & $\begin{array}{l}\text { Основна } \\
\text { група }(n=29)\end{array}$ & $\begin{array}{c}6,25 \pm 0,25 \\
95 \% \text { ДІ: } 5,76-6,74 \\
4-7 \\
n=12\end{array}$ & 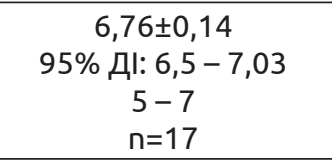 & $\begin{array}{c}6,55 \pm 0,14 \\
95 \% \text { ДІ: } 6,28-6,82 \\
4-7 \\
n=29\end{array}$ & 0,062 \\
\hline & $\begin{array}{l}\text { Порівняльна } \\
\text { група }(n=30)\end{array}$ & $\begin{array}{c}6,43 \pm 0,34 \\
95 \% \text { ДI: } 5,76-7,11 \\
1-8 \\
n=23\end{array}$ & $\begin{array}{c}6,71 \pm 0,18 \\
95 \% \text { ДI: } 6,35-7,08 \\
6-7 \\
n=7\end{array}$ & $\begin{array}{c}6,5 \pm 0,27 \\
95 \% \text { ДІ: } 5,98-7,02 \\
1-8 \\
n=30\end{array}$ & 0,664 \\
\hline \multirow[t]{2}{*}{$\begin{array}{l}\text { Стан плода за } \\
\text { шкалою Апгар, } \\
5 \text { хвилина життя }\end{array}$} & $\begin{array}{l}\text { Основна } \\
\text { група }(n=29)\end{array}$ & $\begin{array}{c}6,83 \pm 0,11 \\
95 \% \text { ДІ: 6,61-7,05 } \\
6-7 \\
n=12\end{array}$ & $\begin{array}{c}7,12 \pm 0,12 \\
95 \% \text { ДІ: } 6,89-7,35 \\
6-8 \\
n=17\end{array}$ & $\begin{array}{c}7,0 \pm 0,09 \\
95 \% \text { Дl: } 6,83-7,17 \\
6-8 \\
n=29\end{array}$ & 0,104 \\
\hline & $\begin{array}{l}\text { Порівняльна } \\
\text { група }(n=30)\end{array}$ & $\begin{array}{c}6,87 \pm 0,13 \\
95 \% \text { ДІ: } 6,61-7,13 \\
5-8 \\
n=23\end{array}$ & $\begin{array}{c}7,0 \pm 0 \\
95 \% \text { Дl: } 7-7 \\
7-7 \\
n=7\end{array}$ & $\begin{array}{c}6,9 \pm 0,1 \\
95 \% \text { ДІ: 6,7 - 7,1 } \\
5-8 \\
n=30\end{array}$ & 0,59 \\
\hline \multirow[t]{2}{*}{$\begin{array}{l}\text { Маса } \\
\text { новонароджених, } \\
\text { гр }\end{array}$} & $\begin{array}{l}\text { Основна } \\
\text { група }(n=29)\end{array}$ & $\begin{array}{c}1508 \pm 152,12 \\
95 \% \text { ДI: } 1209,84- \\
1806,16 \\
1200-2600 \\
n=12\end{array}$ & $\begin{array}{c}2200 \pm 85,02 \\
95 \% \text { ДI: } 2033,36- \\
2366,64 \\
1750-3100 \\
n=17\end{array}$ & $\begin{array}{c}1933,85 \pm 102,02 \\
95 \% \text { ДІ: } 1733,9- \\
2133,79 \\
1200-3100 \\
n=29\end{array}$ & $<0,001$ \\
\hline & $\begin{array}{l}\text { Порівняльна } \\
\text { група }(n=30)\end{array}$ & $\begin{array}{c}1721,14 \pm 88,72 \\
95 \% \text { ДІ: } 1547,26- \\
1895,02 \\
1140-2480 \\
n=23\end{array}$ & $\begin{array}{c}2126,67 \pm 192,63 \\
95 \% \text { ДІ: } 1749,13- \\
2504,21 \\
1480-2800 \\
n=7\end{array}$ & $\begin{array}{c}1808,04 \pm 85,49 \\
95 \% \text { ДІ: } 1640,49- \\
1975,58 \\
1140-2800 \\
n=30\end{array}$ & 0,05 \\
\hline \multirow[t]{2}{*}{$\begin{array}{l}\text { Довжина } \\
\text { новонароджених, } \\
\text { см }\end{array}$} & $\begin{array}{l}\text { Основна } \\
\text { група }(n=29)\end{array}$ & $\begin{array}{c}40,55 \pm 0,91 \\
95 \% \text { ДІ: } 38,77-42,33 \\
36-45 \\
n=12\end{array}$ & $\begin{array}{c}43,69 \pm 0,49 \\
95 \% \text { ДІ: } 42,73-44,65 \\
41-48 \\
n=17 \\
\end{array}$ & $\begin{array}{c}42,41 \pm 0,55 \\
95 \% \text { ДІ: } 41,33-43,49 \\
36-48 \\
n=29\end{array}$ & 0,03 \\
\hline & $\begin{array}{l}\text { Порівняльна } \\
\text { група }(n=30)\end{array}$ & $\begin{array}{c}42,5 \pm 0,7 \\
95 \% \text { ДІ: } 41,12-43,88 \\
37-48 \\
n=23\end{array}$ & $\begin{array}{c}44 \pm 1,7 \\
95 \% \text { ДІ: } 40,66-47,34 \\
38-50 \\
n=7\end{array}$ & $\begin{array}{c}42,86 \pm 0,67 \\
95 \% \text { ДІ: } 41,55-44,17 \\
37-50 \\
n=30\end{array}$ & 0,347 \\
\hline
\end{tabular}

Не викликає сумніву, що проблема ПП залишається в розряді найактуальніших тем сучасного акушерства $[1,2,15,17]$. Народження недоношених дітей шляхом кесаревого розтину не запобігає виникненню перинатальних ускладнень, проте асоційоване з підвищенням материнської захворюванос- ті та смертності. Удосконалення класичних методик та розробка сучасних підходів до оперативного розродження може бути додатковим резервом підвищення ефективності профілактики інтраопераційної крововтрати та деяких неонатальних ускладнень, пов' язаних із абдомінальним розродженням. 
Огляди літератури, оригінальні дослідження, погляд на проблему, випадок з практики, короткі повідомлення

Висновки. Застосування удосконаленої методики абдомінального розродження підвищує ефективність профілактики виникнення МАК, дозволяє майже на 300 мл зменшити величину інтраопераційної крововтрати, сприяє зниженню кількості анемій та гемотрансфузій в інтра- та післяопераційному періоді.

\section{ЛІТЕРАТУРА}

1. Зиядинов А. А. Причины кесарева сечения при преждевременных родах / А. А. Зиядинов, А. Н. Сулима, А. Н. Рыбалка // Таврический медико-биологический вестник. - 2015. - № 1 (69). - С. 44-47.

2. Дяк К. В. Причинні фактори передчасних пологів (новий погляд на проблему) / К. В. Дяк, О. М. Юзько // Неонатологія, хірургія та перинатальна медицина. -2017 . - № 1 (23). - C. 62-68.

3. Preterm labor and birth management: recommendations from the european association of perinatal medicine / G. C. Di Renzo, L. Cabero Roura, F. Facchinetti [et al.] // J. Matern. Fetal. Neonatal. Med. - 2017. - Vol. 30 (17). P. 2011-2030.

4. Краснопольский В. И. Кесарево сечение. Проблемы абдоминального акушерства: рук. для врачей / В. И. Краснопольский ; под. ред. В. И. Краснопольского. - 3-е изд., перера6. и доп. - М. : СИМК, 2018. - 224 с.

5. Каменских Г.В. Возможности прогнозирования кровотечения у женщин с преждевременными родами / Г. В. Каменских, В. А. Новикова // Научное обозрение. Медицинские науки. - 2019. - № 2. - С. 63-73.

6. Бойко В. І. Акушерські кровотечі : навч. посіб. / В. І. Бойко, Т. В. Бабар. - Суми : СДМУ, 2017. - 118 с.

7. Кесарево сечение: показания, методы обезболивания, хирургическая техника: клинические рекомендации / под ред. Л. В. Адамян, В. Н. Серова. - М. : 2013. -29 c.

8. Корчинська О. О. Материнські та перинатальні наслідки, пов'язані з кесаревим розтином: порівняльний аналіз із досвідом колег зі Словаччини / О.О.Корчинська, К. Ю. Гульпе // Проблеми клінічної педіатрії. 2013. - № 3 (21). - С. 35-39.

9. Фаткуллин И. Ф. Кесарево сечение с извлечением плодов в целом плодном пузыре при беременности двойней / И. Ф. Фаткуллин, Н. Р. Ахмадеев, Ф. И. Фаткуллин // Акушерство и гинекология. - 2015. - № 2 (8). С. 29-32.

10. Assisted reproductive technology surveillance - United States, 2010 / S. Sunderam, D. M. Kissin, S. Crawford [et al.] // MMWR Surveill. Summ. - 2013. - Vol. 62 (9). - P. 1-24.

11. Puerperal morbidity following repeat cesarean delivery in twin pregnancies / A. Trojner-Bregar, N. Tul, I. Verdenik [et al.] // Gynecol. Obstet. -2013. - Vol. 288 (3). P. 551-554.

12. A randomized trial of planned cesarean or vaginal delivery for twin pregnancy / J. F. Barrett, M. E. Hannah, E. K. Hutton [et al.] // N. Engl. J. Med. - 2013. - Vol. 369 (14). P. 1295-305.

13. Birth trauma - risk factors and short-term neonatal outcome / N. Linder, I. Linder, E. Fridman [et al.] // J. Matern. Fetal. Neonatal. Med. - 2013. - Vol. 26 (15). - P. 1491-1495.
Перспективи подальших досліджень. Провести поглиблене дослідження з розширенням клінічних груп за гестаційним терміном та кількістю пацієнток. Проаналізувати вплив модифікованої методики кесаревого розтину на частоту виникнення перинатальних ускладнень.

14. Сарбасова А. Е. Оптимизация методов снижения кровопотери при операции кесарева сечения : автореф. дисс. на соискание науч. степени канд. мед. наук : спец. 14.01.01 / Аида Ерболатовна Сарбасова. Астрахань, 2018. - 175 с.

15. Передчасні пологи: протиріччя та сучасні реалії / В. П. Лакатош, Т. Т. Наритник, В. В. Біла [та ін.] // Здоровье женщины. - 2014. - № 7 (93). - С. 10-18.

16. Егорова Я. А. Задержка внутриутробного развития плода в перинатальной медицине (о6зор) / Я. А. Егорова, В. А. Заболотнов, А. Н. Рыбалка // Здоровье женщины. - 2015. - № 4. - С. 48-51.

17. Башмакова Н. В. Сверхранние преждевременные роды: новые результаты. Оптимизация клинических исходов преждевременных родов: опыт Уральского федерального округа / Н. В. Башмакова // Status Praesens. - 2014. - № 6 (23). - C. 13-19.

18. Знаменська Т. К. Діагностика гіпоксично-ішемічного ураження головного мозку в недоношених новонароджених у гострому періоді / Т. К. Знаменська, Л. Г. Кирилова, В. Б. Швейкіна // Перинатологія та педіатрія. - 2013. - № 2 (54). - С. 26-30.

19. Comparative analysis of intraoperative blood loss during the classical cesarean section described by M. Stark and the modified cesarean section / I. Z. Gladchuk, I. V. Shpak, Y. V. Herman, D. O. Hryhurko // Wiad. Lek. 2019. - Vol. 12 (72). - P. 2329-2333.

20. Порівняльний аналіз неонатальних наслідків після класичного (за M. Stark) та модифікованого кесаревого розтину при передчасних пологах / І. З. Гладчук, А. Г. Волянська, Ю. В. Герман, Д. О. Григурко // Вісник Вінницького національного медичного університету. 2019. - № 3 (23). - С. 414-419.

21. Клінічний протокол з акушерської допомоги «Кесарів розтин» // Наказ МОЗ України від 27.12.2011 № 977. - URL: http://old.moz.gov.ua/ua/portal/dn_20111227_977.

22. Сравнительная характеристика послеродовых кровотечений в различные сроки беременности / В. А. Новикова, Г. В. Каменских, А. А. Авакимян [и др.] // Современные проблемы науки и образования. - 2018. № 1. - С. 202-208.

23. Ниязметов Р. Э. Особенности лечения массивного акушерского кровотечения в ретроспективной группе / Р. Э. Ниязметов, Б. Б. Матякубов, Д. М. Хабибуллаев // Медицина неотложных состояний. - 2020. № 4 (16). - С. 70-74.

24. Герман Ю. В. Чи можливо дивитися на будь-яку медичну спеціальність очима іншого спеціаліста? Мультидисциплінарний підхід на основі власного досвіду / Ю. В. Герман, Д. О. Григурко // Здоров' я жінки. - 2018. № 1 (58). - С. 30-32. 
Огляди літератури, оригінальні дослідження, погляд на проблему, випадок з практики, короткі повідомлення REFERENCES

1. Ziyadinov, A.A, Sulima, A.N, \& Rybalka, A.N. (2015). Prichiny kesareva secheniya pri prezhdevremennykh rodakh [Reasons for caesarean section in preterm labor]. Tavricheskiy mediko-biologicheskiy vestnik - Tauride medical and biological bulletin, 1 (69), 44-47 [in Russian].

2. Dyak, K.V, \& Yuzko, O.M. (2017). Prychynni faktory peredchasnykh polohiv (novyi pohliad na problemu) [Causal factors of premature birth (a new look at the problem)]. Neonatolohiya, khirurhiya ta perynatalna medytsyna- Neonatology, surgery and perinatal medicine, 1 (23), 62-68 [in Ukrainian].

3. Di Renzo, G.C., Cabero Roura, L., Facchinetti, F., Helmer, H., Hubinont, C., Jacobsson, B., \& Visser, G.H.A. (2017). Preterm labor and birth management: recommendations from the european association of perinatal medicine. J. Matern. Fetal. Neonatal. Med., 30 (17), 2011-2030.

4. Krasnopolsky, V.I. (Ed.) (2018). Kesarevo secheniye. Problemy abdominalnogo akusherstva: ruk. dlya vrachey [Cesarean section. Problems of abdominal obstetrics: a guide for doctors]. 3rd ed., revised. and add. Moscow: SIMK [in Russian].

5. Kamenskikh, G.V., \& Novikova, V.A. (2019). Vozmozhnosti prognozirovaniya krovotecheniya u zhenshchin s prezhdevremennymi rodami [Possibilities for predicting bleeding in women with preterm labor]. Nauchnoye obozreniye. Meditsinskiye nauki-Sci. Rev. Med. Sci., 2, 63-73 [in Russian].

6. Boyko, V.I., \& Babar, T.V. (Ed.) (2017.) Akusherski krovotechi: navch. posib. [Obstetric bleeding: a textbook]. Sumy: SDMU [in Ukrainian].

7. Adamyan, L.V., \& Serova, V.N. (2013). Kesarevo secheniye: pokazaniya, metody obezbolivaniya, khirurgicheskaya tekhnika: klinicheskiye rekomendatsii [Caesarean section: indications, methods of anesthesia, surgical technique: clinical guidelines]. Moscow [in Russian].

8. Korchinska, O.O., \& Gulpe, K.Yu. (2013). Materynski ta perynatalni naslidky, poviazani z kesarevym roztynom: porivnialnyi analiz iz dosvidom koleh zi Slovachchyny [Maternal and perinatal inheritance, tied with caesarean rostin: a preliminary analysis from the previous colleagues from Slovakia]. Problemy klinichnoi pediatrii- Problems of Clinical Pediatrics, 3 (21), 35-39 [in Ukrainian].

9. Fatkullin, I.F, Akhmadeev, N.R, \& Fatkullin, F.I. (2015). Kesarevo secheniie s izvlecheniem plodov v tselom plodnom puzyre pri beremennosti dvoyney [Cesarean section with the extraction of fetuses in the whole fetal bladder during pregnancy with twins]. Akusherstvo i ginekologiya - Obstetrics and Gynecology, 2 (8), 29-32 [in Russian].

10. Sunderam, S., Kissin, D.M., Crawford, S., Anderson, J.E., Folger, S.G., Jamieson, D.J., \& Barfield, W.D. (2013). Assisted reproductive technology surveillance United States, 2010. MMWR Surveill. Summ., 62 (9), 1-24.

11. Trojner-Bregar, A., Tul, N., Verdenik, I., Novak, Z., \& Blickstein, I. (2013). Puerperal morbidity following repeat cesarean delivery in twin pregnancies. Obstet. Gynecol., 288 (3), 551-554. DOI: 10.1007/s00404-013-2818-8

12. Barrett, J.F., Hannah, M.E., Hutton, E.K., Willan, A.R., Allen, A.C., Armson, B.A., \& Asztalos, E.V. (2013). A randomized trial of planned cesarean or vaginal delivery for twin pregnancy. N. Engl. J. Med., 369 (14), 1295-1305. DOI: 10.1056/NEJMoa1214939
13. Linder, N., Linder, I., Fridman, E., Kouadio, F., Lubin, D., Merlob, P., \& Melamed, N. (2013). Birth trauma risk factors and short-term neonatal outcome. J. Matern. Fetal. Neonatal. Med., 26 (15), 1491-1495. DOI: 10.3109/ 14767058.2013.789850

14. Sarbasova, A.E. (2018). Optimizatsiya metodov snizheniya krovopoteri pri operatsii kesareva secheniya [Optimization of methods for reducing blood loss during cesarean section]. Candidate's thesis. Astrakhan [in Russian].

15. Lakatosh, V.P., Narytnyk, T.T., Bila, V.V., Aksonova, A.V., \& Tkalich, V.O. (2014). Peredchasni polohy: protyrichchia ta suchasni realii [Premature birth: contradictions and modern realities]. Zdorovye zhenshchyny - Women's Health, 7 (93), 10-18 [in Russian].

16. Egorova, Ya.A., Zabolotnov, V.A., \& Rybalka, A.N. (2015). Zaderzhka vnutriutrobnogo razvitiya ploda v perinatalnoy meditsine (obzor) [Delayed intrauterine development of the fetus in perinatal medicine (review)]. Zdorovye zhenshchyny - Women's Health, 4, 48-51 [in Russian].

17. Bashmakova, N.V. (2014). Sverkhranniye prezhdevremennyye rody: novyie rezultaty. Optimizatsiya klinicheskikh iskhodov prezhdevremennykh rodov: opyt Uralskogo federalnogo okruga [Very early preterm labor: new results. Optimization of clinical outcomes of preterm birth: the experience of the Ural Federal District]. Status Praesens, 6 (23), 13-19 [in Russian].

18. Znamenska, T.K., Kirilova, L.G., Shveikina, V.B. (2013). Diahnostyka hipoksychno-ishemichnoho urazhennia holovnoho mozku $v$ nedonoshenykh novonarodzhenykh u hostromu periodi [Diagnostics of hypoxic-ischemic lesion of the brain in preterm neonatal infants in the state of emergency]. Perynatolohiya ta pediatriya - Perinatology and Pediatrics, 2 (54), 26-30 [in Ukrainian].

19. Gladchuk, I.Z., Shpak, I.V., Herman, Y.V., \& Hryhurko, D.O. (2019). Comparative analysis of intraoperative blood loss during the classical cesarean section described by $M$. Stark and the modified cesarean section. Wiad. Lek., 12 (72), 2329-2333.

20. Hladchuk, I.Z., Volianska, A.H., Herman, Yu.V., \& Hryhurko, D.O. (2019). Porivnialnyi analiz neonatalnykh naslidkiv pislia klasychnoho (za M. Stark) ta modyfikovanoho kesarevoho roztynu pry peredchasnykh polohakh [Comparative analysis of neonatal consequences after classical (according to M. Stark) and modified cesarean section in premature birth]. Visnyk Vinnytskoho natsionalnoho medychnoho universytetu - Bulletin of Vinnytsia National Medical University, 3 (23), 414-419 [in Ukrainian].

21. (2019). Klinichnyi protokol z akusherskoi dopomohy "Kesariv roztyn". Clinical protocol for obstetric and gynecological care «cesarean section». Nakaz Ministerstva okhorony zdorovia Ukrainy. Order of the Ministry of Health of Ukraine. No. 977 Retrieved from: http://old.moz.gov.ua/ ua/portal/dn_20111227_977 [in Ukrainian].

22. Novikova, V.A., Kamenskikh, G.V., Avakimyan, A.A., Khorolsky, V.A., \& Chernobay, E.G. (2018). Sravnitelnaya kharakteristika poslerodovykh krovotecheniy v razlichnyie sroki beremennosti [Comparative characteristics of postpartum bleeding at different stages of pregnancy]. Sovremennyye problemy nauki i obrazovaniya-Modern Probl. Sci. Educ., 1, 202-208 [in Russian]. 
Огляди літератури, оригінальні дослідження, погляд на проблему, випадок з практики, короткі повідомлення

23. Niyazmetov, R.E., Matyakubov, B.B., \& Khabibullaev, D.M. (2020). Osobennosti lecheniya massivnogo akusherskogo krovotecheniya v retrospektivnoy gruppe [Features of the treatment of massive obstetric bleeding in the retrospective group]. Meditsina neotlozhnykh sostoyaniy - Emergency Medicine, 4 (16), 70-74 [in Russian].
24. Herman, Yu.V., \& Hryhurko, D.O. (2018). Chy mozhlyvo dyvytysia na bud-yaku medychnu spetsialnist ochyma inshoho spetsialista? Multydystsyplinarnyi pidkhid na osnovi vlasnoho dosvidu [Is it possible to look at any medical specialty through the eyes of another specialist? Multidisciplinary approach based on personal experience]. Zdorovia zhinky - Women's Health, 1 (58), 30-32 [in Ukrainian].

\section{СРАВНИТЕЛЬНЫЙ АНАЛИЗ ИНТРАОПЕРАЦИОННОЙ КРОВОПОТЕРИ ПРИ ПРЕЖДЕВРЕМЕННЫХ РОДАХ ВО ВРЕМЯ КЕСАРЕВА СЕЧЕНИЯ КЛАССИЧЕСКИМ СПРОСОБОМ ПО МОДИФИЦИРОВАННОЙ МЕТОДИКЕ}

\section{Одесский национальний медицинский университет}

๑Д. А. Григурко

РЕЗЮМЕ. Цель - провести сравнительный анализ объема интраоперационной кровопотери при кесаревом сечении (КС) по классическому способу и при применении модифицированной методики в условиях преждевременных родов (ПР).

Материал и методы. Проведен сравнительный анализ 59 случаев преждевременных родов, родоразрешение которых было проведено абдоминальным путем. Основную группу (І клиническая) составили 29 пациенток, у которых операция кесарева сечения выполнялась согласно предложенной модифицированной методике, сравнительную группу (II клиническая) - 30 пациенток, которые были прооперированы классическим способом КС. Для более достоверного анализа каждая клиническая группа была поделена на две подгруппы в зависимости от срока беременности (29-33 недель и 6 дней и 34-36 недель и 6 дней соответственно). Главные отличия предложенной методики абдоминального родоразрешения заключаются в использовании усовершенствованного способа вхождения в брюшную полость и в одномоментном ушивании раны на матке двумя операторами, начиная от углов раны непрерывным однорядным викриловим швом с фиксирующей петлей на каждом из концов двух нитей. В случаях рождения детей на ранних сроках, до 30 недель гестации, проводился корпоральный разрез на матке и их рождение в целом плодном пузыре.

Результаты. В процессе исследования нами выявлено, что применение модифицированной методики абдоминального родоразрешения способствует уменьшению величины интраоперационной кровопотери при ПП почти на 300 мл (р<0,001), минимизирует развитие массивных акушерских кровотечений (МАК), практически аннулирует потребность в проведении интраоперационной гемотрансфузии и гистерэктомии $(p<0,05)$.

Вывод. Полученные нами данные подтверждают эффективность применения усовершенствованной методики абдоминального родоразрешения для уменьшения объема интраоперационной кровопотери при ПР.

КЛючЕВЫЕ СЛОВА: кесарево сечение; преждевременные роды; кровопотеря; модификация.

\section{COMPARATIVE ANALYSIS OF INTRAOPERATIVE BLOOD LOSS IN PREMATURE CHILDBIRTH CESARANEAN SECTION BY CLASSICAL METHOD AND MODIFIED METHODOLOGY}

@D. O. Hryhurko

\section{Odesa National Medical University}

SUMMARY. The aim - to carry out a comparative analysis of the volume of intraoperative blood loss during cesarean section (CS) according to the classical method and when using a modified technique in conditions of preterm labor (PL).

Material and Methods. A comparative analysis of 59 cases of preterm birth, the delivery of which was by the abdominal route, was carried out. The main group (clinical I) consisted of 29 patients in whom the caesarean section was performed according to the proposed modified technique. Comparative group (II clinical) - 30 patients who were operated on by the classical CS method. For a more reliable analysis, each clinical group was divided into two subgroups depending on the gestational age (29-33 weeks 6 days and 34-36 weeks and 6 days, respectively). The main differences of the proposed method of abdominal delivery are the use of an improved method of entering the abdominal cavity and simultaneous suturing of the wound on the uterus by two operators, starting from the corners of the wound with a continuous single-row vicryl suture with a fixing loop at each of the ends of two threads. In cases of the birth of children in the early stages of up to 30 weeks of gestation, a corporal incision in the uterus and their birth in the whole fetal bladder.

Results. We found that the use of a modified technique of abdominal delivery helps to reduce the amount of intraoperative blood loss in PL by almost $300 \mathrm{ml}(\mathrm{p}<0.001)$, minimizes the development of massive obstetric bleeding (MAC), virtually eliminates the need for intraoperative blood transfusion and hysterectomy $(p<0.05)$.

Conclusions. The data confirm the effectiveness of using the improved technique of abdominal delivery to reduce the volume of intraoperative blood loss in PR.

KEY WORDS: cesarean section; premature birth; blood loss; modification. 